\title{
TRAFFICKING OF PERSONS IN SUDANESE LAW IS A COMPARATIVE STUDY WITH REGIONAL AND INTERNATIONAL CONVENTIONS
}

\section{ZUBEIDA ATIM}

Prince Sultan University Riyadh, Saudi Arabia

ABSTRACT
Humanity has known in the past many forms of slavery, different forms from one country to another and
disappeared in a period of periods, but it returned in the phenomenon of crime of trafficking in human beings. In a more
criminal and brutal manner, in a widespread phenomenon in East African countries (1)
The Republic of Sudan is experiencing the transit of African migrants, especially in the east of the country,
many continue after arrival For the Sudan their trip to other countries aimed at the European continent or the American
continent, the aim of the position.
This topic is aimed at To learn about anti-trafficking laws in Sudan and compare them to international
Conventions In particular the Protocol to Prevent, Suppress and Punish Trafficking in Persons, Especially Women and
KEYWORDS: Humanity, African migrants \& Transnational Organized Crime

Received: Nov 16, 2017; Accepted: Dec 06, 2017; Published: Dec 12, 2017; Paper Id.: IJPSLIRDEC20173

\section{TERMINOLOGY}

Trafficking in persons is a process of buying, selling, and smuggling, kidnapping or exploiting persons

\section{INTRODUCTION}

Several African countries have passed national laws to combat human trafficking since the ratification of the UN Protocol to Prevent, Suppress and Punish Trafficking in Persons In line with the legislative obligation accompanying the United Nations Protocol

Sanctions and measures have been put in place to curb this phenomenon, and in the context of this we will focus our attention on Sudan as an African country

Which deals with the crime of trafficking in human beings, while monitoring the most important conventions and conventions that dealt with the protection of children and women from trafficking and exploitation,

This section is divided into three sections: Section I The concept of trafficking in human rights in

\footnotetext{
(1) World Program Against Trafficking in Human Beings - United Nations New York 2006 - P.13

${ }^{2)}$ )Dr. Rami Metwally Judge: Combating Trafficking in Human Beings - Arab Renaissance House - Cairo - 1998 - $p$

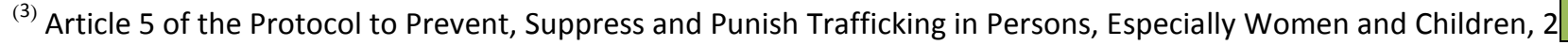


international conventions and Sudan, and Section II: We highlight the most important images of the crime of trafficking in human beings in Sudan, and the third part measures against trafficking in human beings. And then the conclusions and recommendations we have reached in this article.

\section{Section I: The Concept of Human Trafficking in International Conventions and Sudanese Law}

Definition of human trafficking as exploitation in prostitution and other forms of sexual exploitation and child pornography, forced labor, forced servitude, slavery or practices similar to slavery, exclusion, begging, removal of organs or human tissues or part thereof.(1)

Defined by the United Nations Convention on Transnational Organized Crime 2002 (2) As a recruitment, transfer, transfer, harboring or reception of individuals by means of The threat or use of force or any other forms of coercion, abduction, fraud, deception, abuse of power, exploitation of weaknesses or the granting of sums or benefits to obtain the consent of a person who has control over another for the purpose of exploitation, exploitation, prostitution or any form of sexual exploitation and employment Forced service, servitude or similar practices or removal of organs.

Amnesty International defined it as a "violation of human rights including the right to physical and mental integrity, liberty, security of the person, dignity and freedom from slavery, torture, other inhuman or degrading treatment, family life, freedom of movement and privacy .(1)

Article 3 (a) of the Protocol to Prevent, Suppress and Punish Trafficking in Persons, Especially Women and Children, states that it is the recruitment, transportation, removal, harboring or receiving of persons by threat or use of force or other forms of coercion, abduction, fraud, deception or exploitation Authority or exploitation of a situation of vulnerability, or by giving or receiving payments or benefits to obtain the consent of a person having control over another person for the purpose of exploitation. Exploitation shall include, at a minimum, the exploitation of the prostitution of others or other forms of sexual exploitation, forced labor or servitude, slavery or practices similar to slavery, servitude or removal of organs.

In accordance with the Universal Declaration of Human Rights in 1998 and the African Charter on Human and Peoples' Rights (2) Everyone has the right to life, liberty and security of person. The Sudanese Constitution of 2005 is in conformity with international and regional conventions. It affirms that everyone has an inherent right to life, dignity and personal integrity. The law protects this right. No one shall be arbitrarily deprived of life. Everyone has the right to liberty and security. No one shall be subject to arrest or imprisonment. He shall not be deprived of his liberty or restricted except for reasons and in accordance with procedures established by law(3)

${ }^{(1)}$ Dr. Saad Eddin Mosaad Hilali: The new in Islamic jurisprudence contemporary - Library Wahba - Cairo - 2010 - p. 431

(2) The United Nations Convention against Transnational Organized Crime is a United Nations-sponsored multilateral treaty against organized crime. The Convention was adopted by a resolution of the United Nations General Assembly on 15 November 2000 . The Palermo Convention and its three Protocols (the Palermo Protocols) are also known as the Protocol to Prevent, Suppress and Punish Trafficking in Persons, Especially Women and Children. protocol

${ }^{(1)}$ Document No. 034/009/2005

${ }^{(2)}$ The African Charter on Human and Peoples 'Rights, which was adopted by the African Presidents' Council at its 18th regular session in Nairobi, Kenya, in June 1981

${ }^{(3)}$ The Constitution of the Republic of the Sudan was promulgated in 2005, after it was approved by the Sudanese Parliament and signed by the President of the Republic. It is based on the Comprehensive Peace Agreement signed in January 2005 and guided by the Sudan Constitution of 1998. 
The Sudanese Constitution prohibits slavery and slave trade in all its forms, and no one may be held in slavery or subjected to forced labor. No one may be compelled to perform forced labor except as a sentence of conviction by a competent court .(1)

Sudan ratified the Protocol to Prevent, Suppress and Punish Trafficking in Persons, Especially Women and Children, in 2013 with the enactment of a law against trafficking in human beings in 2014.

Anyone who lures, transports, abducts, transports, shelters, receives, detains or equips natural persons for the purpose of exploiting them or using them for illegal acts, for achieving unlawful objectives in exchange for obtaining a material return, Promise it, earn moral, or promise it, or grant any kind of benefits.

The Sudan Criminal Code of 1991 in Section 16 of the Penal Code of 1991 on the crime of extortion, kidnapping and forced labor as a crime of human trafficking affecting the right of persons to personal liberty. The Sudanese legislature has also enacted a law to protect children from this phenomenon as well as to prohibit their use in armed conflicts. In the sixth chapter of the law of informatics crimes in 2007, the courts set up websites for the purpose of trafficking in the human race. The penalty was increased to ten years.

\section{Section II: Human Trafficking in Sudan}

The target groups in human trafficking and exploitation in Sudan are women children and therefore we review the forms of human trafficking:

Sexual exploitation of women by forced prostitution and carried out by individuals or criminal organizations of an international character or by illegal trafficking of women from neighboring African countries or the abduction of women

(1)As part of the protection and rights of women, Sudan has ratified a number of international conventions including:

Protocol on the Rights of Women in Africa, annexed to the African Charter on Human and Peoples' Rights, adopted by the General Assembly of Heads of State and Government of the African Union, in Maputo on 11 July 2003.

The UN Convention relating to the Status of Refugees of 1951 and the Protocol relating to the Status of Refugees of 1967 ;

United Nations Convention against Corruption and the Slavery Convention agreement Prohibition of trafficking in persons and exploitation of the prostitution of others, the first article of which stipulates that the parties to the Convention agree to punish any person who, to satisfy other passions. By procuring, deceiving or misleading another person, on the purpose of prostitution, even with the consent of that person, or. By exploiting the prostitution of another person, even with the consent of that person .(1)

The Sudanese Criminal Code of 1991 on crimes that constitute trafficking in women. The manufacture of articles and offers against literature and the crime of prostitution and the management of a place of prostitution and seduction and

${ }^{(1)}$ Document of Rights - Part II of the Sudanese Constitution 2005 p

(1) د عبد القادر الثيخلي : جر ائم الاتجار بالاشخاص و الاعضاء البشرية وعقوباتها في الثريعة الاسلامية و القوانين العربية والقانون الدولي - منشور ات الحلبي

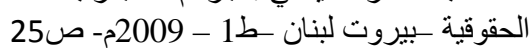

${ }^{(1)}$ Convention on the Suppression of the Traffic in Persons and of the Exploitation of the Prostitution of Others Adopted and offered for signature, ratification and accession by the United Nations General Assembly resolution 317 (IV), 2

December 1949 Entry into force: 25 July 1951, article 24 
punish them with flogging and imprisonment 2Article (20) of the Sudanese Computer Crime Act of 2007 in chapter 6 states that "Anyone who creates or publishes a Web site or a computer or similar device for the purpose of trafficking in the human race or facilitating the dealing Shall be punished by imprisonment for a term not exceeding ten years or by a fine or both"

\section{Trafficking in Children}

The crime of trafficking in children has been linked to the so-called sexual slavery of gangs engaged in prostitution, the sale of embryos, the abduction of children and their use in professional or criminal activities(1)

Child under the Convention on the Rights of the Child: Every person under the age of eighteen years unless he or she has attained the age of majority under the law applicable to the child, Sudan was interested in children, agreeing to international and regional conventions Interested in protecting children (1)

Sudan joined the African Protocol on the Rights and Welfare of the Child, 1990 which obliges signatory States to take appropriate measures to prevent the abduction, sale or trafficking of children for any purpose or in any form whatsoever by any person, including parents or legal guardians of the child, Children in all forms of begging(2)

The Sudanese Child Act 2010 prohibits the trafficking of children, the exploitation of children in prostitution, pornography and forced labor Each person commits a crime against the child when abducting or selling a child or transporting a member or members of any child, Sexually harass or sexually abuse any child, produce, distribute, publish, import, export, display, sell or possess any child pornography (3), Any child is used for the purpose of sexual activities for remuneration or any form of compensation, Encourages or depicts by any means any child practicing a real practice or simulating explicit sexual activities or depicting sexual organs of any child to satisfy sexual desire.

Sudan has joined the Optional Protocol to the Convention on the Rights of the Child on the involvement of children in armed conflict.(3) Article 46 of the Sudanese Child Act of 2010 prohibits the use of children in forced the perpetrator is a person who has escaped or assisted in the smuggling of any child or children across the border for the purpose of forced labor, trafficking, forced use or violence in its forms.

\section{Human Member Trade}

Is a trade in eastern Sudan targeting Eritrean refugee camps on the border between Sudan and Eritrea, which is located near the eastern city of Kassala, where the refugees are being kidnapped forcibly, transferring them and killing them in exchange for the sale of their human organs 1)

Dr.. Mohammed Yahia: International Efforts to Combat Human Trafficking - Riyadh - Naif University for Security ${ }^{(2)}$ Sciences - 2010 - p. 444

${ }^{1)}$ Sudan ratified the Optional Protocols to the Convention on the Rights of the Child without reservations on 11 September 2004 and thus became part of the Sudan legislation. The competent judicial organs and other relevant bodies have been informed of the contents of these Protocols.

${ }^{(2)}$ The African Charter on the Rights and Welfare of the Child 1990 was introduced on 29 November 1999 , article 29

${ }^{(3)}$ Article 45 of the Sudanese Child Act 2010

${ }^{1}$ Adopted and opened for signature, ratification and accession by United Nations General Assembly resolution 263 Fiftyfourth session of 25 May 2000 Entered into force 23 February 2002 
The Sudanese legislator defined the human tissue law in 1978 as the member, who performs any sensory function in the human body.

There is no universally accepted concept of the crime of trafficking in human organs, since the crime of trafficking in human organs is a new crime against the international community. The crime consists of three forms: the first removal of the human body, a form of human trafficking as set forth in the 2000 Palermo Protocol; The second form is: organ transplant tourism, which is the travel of the beneficiary to one of the developing countries with the intention of transplanting organs Human beings who have been illegally removed or bought from a local citizen

And the third: the kidnapping, killing and taking of members and their transfer to another state.(1)

In 2004, the United Nations General Assembly passed a resolution banning, combating and criminalizing trafficking in human organs, as well as Article 9 of the Arab Charter on Human Rights, 2004, which prohibits medical or scientific experiments on any person or exploits his organs without his free consent and full understanding of the complications presented to them, Taking into account the ethical, human and professional rules and regulations and adherence to the necessary medical procedures to guarantee his personal safety in accordance with the legislation in force in the State. In no case shall human trafficking be permitted..( (2)

\section{Sudanese Legislator of Transplant and Transplantation of Human Organs}

The Sudanese legislator in the law of members and human tissues in 1978 organized the organizational and legal aspects of the mechanism of transplantation and transplantation of human organs, and the aim of the law to achieve the following(1) :

Prohibition of trafficking in organ transplants, tissues and human cells.

- Prohibition of the removal or trade of organs, as well as the cases in which the removal of organs from the living person is permitted and cultivated for educational or medical purposes- (2) .The establishment of controls for the conservation, transport and transplantation of tissue and human cells whether transferred from the living or dead.

Where the law defines the sale of human organs Sudanese medical implant: that The removal of any organ or tissue from a deceased person unless the deceased person has consented to it in writing or orally in the presence of two witnesses, Or if the nearest relative agrees to do so after death, provided that the deceased person has not objected in his life to the removal of any organ or tissue from his body (3) And if the patient dies in any hospital or social institution, and no relative or person who takes care of his body should be removed only after the consent of the competent authority

(1) Vladimir Ma Kihekeli: Trafficking in Human Organisms - Forced Migration Bulletin. Emilycelli: The Crisis of International Human Organ Transplantation Solutions to Address the Roots of the Case: A Report by the Journal of the Faculty of Law, Boston University, 2013

${ }^{(2)}$ Arab Charter on Human Rights - League of Arab States, 22 May 2004, entered into force on 15 March 0082

(1) Zuhair Al-Khalifa Al-Hussein: Legislation Applied in the Arab World in the Field of Combating Human Trafficking Comparisons in Facing these Crimes (Khartoum, Sudan, 2016)

\footnotetext{
${ }^{(2)}$ Article (5) of the law of members and human tissues of Sudan 1978

(3) Article (4) of the law of the members and human tissues of Sudan 1978
} 
or the person responsible for the social institution concerned (1) Violation of these legal regulations is a violation of Sudanese law and the penalty of death or imprisonment for a term not exceeding twenty years.

\section{Section III: Controls to Combat Trafficking in Persons}

The problem of trafficking in human beings is now the most important and most serious problems facing Sudan and African countries for the following reasons:

Human trafficking violates human rights recognized in international conventions, covenants and constitutions. The trafficking of organized crime, which is the third crime globally according to the United Nations after the arms and drugs trade.

Human trafficking undermines the prestige of the state (1).

Palermo has developed a package of measures to assist and protect victims of trafficking in persons :

- Each State Party shall, in such cases as may be necessary and to the extent permitted by its domestic law, To preserve the personal sanctity and identity of victims of trafficking in persons, including by making legal proceedings related to such trafficking confidential

- Each State shall ensure that its domestic legal or administrative system contains measures to provide victims of trafficking in persons, where appropriate: a statement of information on judicial and administrative proceedings protecting victims of trafficking; and a statement of assistance that enables victims to view and take into account their views At appropriate stages of criminal proceedings against offenders, without prejudice to the rights of the defense.

- Law enforcement, immigration and other relevant authorities of States Parties shall cooperate among themselves, as appropriate, through the exchange of information in accordance with their domestic law(1)

- Law enforcement, immigration and other relevant authorities of States Parties shall cooperate among themselves, as appropriate, through the exchange of information in accordance with their domestic law In accordance with the directives of the Protocol, a Sudanese national committee was established to enforce the provisions of the Sudanese Human Trafficking Law on 30/4/2014. It is called the National Committee for Combating Trafficking in Human Beings Its functions include: (2)

- Review and submit proposals and recommendations on anti-trafficking legislation,

- Coordination between official and non-official bodies concerned with the prevention of human trafficking crimes, including the necessary procedures to facilitate the return of victims to the country, the competent authorities of the State with the concerned authorities of other countries to facilitate the return of foreign victims to their country according to the necessary procedures in the State,

${ }^{(1)}$ Article (6) of the Sudanese Organ and Human Organism Act 1978

(2) Dr.. Adel Hassan Ali: Human Trafficking Criminalization and Response Mechanisms Center of Studies and Research Naif Arab University for Security Sciences - Riyadh 20012

${ }^{(1)}$ Article 10 of the Palermo Protocol, 2000

${ }^{2}$ Article 5 of the Sudanese Human Trafficking Act of 2014 
- To raise awareness of issues related to trafficking in human beings through the holding of conferences, seminars, publications, training and other means, especially for employers and dealers in the use of workers and employees,

- Strengthening the national capacities of workers in the field of combating human trafficking crimes,

- Issuing and disseminating a national guide that includes guidelines and educational materials relevant to its work

- To study the international, regional and local reports related to combating human trafficking and to take the necessary measures and measures thereon .

Second: A number of specialized prosecution offices have been opened in human trafficking, and a competent court has been appointed to deal with trafficking crimes.(1)

ثالثا:The penalties set forth in the Anti-Human Trafficking Act are a deterrent to anyone who commits a crime of human trafficking The Anti-Human Trafficking and Smuggling of Persons Act, 2014, commits the death penalty or imprisonment for a term of not less than five years and does not exceed 20 years for the perpetrators of the crime of trafficking in any of the following cases

- Had established, established, organized or managed an organized criminal group, led or advocated accession to an organized criminal group.

- The victim was a female or a child under the age of 18 or disabled.

- The crime of human trafficking was committed through fraud, use of force, threat of death, physical or psychological torture.

- The act was committed by two or more persons or by a person carrying a weapon .5The offender was a husband of the offender, one of his descendants, his descendants or his guardian, or he had authority over him.

- The crime was of a transnational nature.

- If any of the victims of human trafficking are subjected to sexual exploitation, removal of organs or use in prostitution.

- The perpetrator of the crime of trafficking in persons was a public official or a public service officer and the offense was committed by exploiting his or her position..

- The crime resulted in the victim being permanently disabled or ineligible.

Fourth: The Council of Ministers approved the draft of the Passports and Immigration Law for the year 2012 which abolishes the Passport and Immigration Law of 1994 , the law punishes acts that were not previously criminal, despite their violation of the sovereignty and security of the state, such as human trafficking. The law requires every foreigner who enters the country to register within a limited period of time, and the law provides for deterrent penalties for

${ }^{(1)}$ Article (30) of the Sudanese Human Trafficking Act 2014 and Article (31) of the same law

${ }^{(1)}$ Article 9 of the Human Trafficking Law passed by the National Assembly at the 24th Session of the Eighth Session, corresponding to 19 January 2014 
the crimes stipulated by the law. But the project has not yet been approved1)

\section{CONCLUSIONS}

In this article we have dealt with a human rights issue, namely human trafficking in the international convention and international conventions, especially in Sudanese law, by criminalizing acts that constitute the crime of trafficking in human beings and to establish appropriate penalties through fair trials in a specialized court. To that end, a national committee should be formed to monitor and combat human trafficking crimes in Sudan. The following are the main results:

- Sudan is concerned with the fight against trafficking in human beings. This is the interest in organizing the AntiHuman Trafficking Act of 2014

- Sudan's accession to the International Convention to Prevent, Suppress and Punish Trafficking in Persons, Especially Women and Children, 2000

- $\quad$ specialized in the investigation of crimes of trafficking in human beings .

- The Sudanese National Committee against Trafficking in Human Beings plays an important role in spreading community awareness and combating human trafficking through seminars, workshops, coordination among relevant authorities and reviewing laws to combat trafficking.

- The penalties stipulated in the Sudanese Anti-Human Trafficking Act of 2014 are deterrent penalties for the perpetrator and also achieve general deterrence for anyone who wants to commit a crime of human trafficking.

\section{RECOMMENDATIONS}

- Establishment of a specialized Sudanese police to combat trafficking in human beings with training in the detection of human trafficking crimes.

- Continuing training of specialized prosecutors and judges concerned with the prosecution of human trafficking cases in Sudan and outside the Sudan

- Establishment of specialized social centers to shelter and assist victims of trafficking in the Sudan.

- Amendment of the law of the sale of human organs of Sudan in 1978, especially with regard to criminal penalties for offenders.

- Legislation of Sudanese law regulating the entry and residence of foreigners in Sudan to reduce the illegal migration of victims of human trafficking

- Establish an African office to prosecute those responsible for trafficking in human beings in East Africa - . 8 Creation of cooperation between the countries of the Horn of Africa, the United Nations and all international and regional bodies

- Convening of African conferences and workshops for the relevant bodies related to human trafficking crimes

- Activating the role of the African media in alerting to the phenomenon of human trafficking and its means and

${ }^{(1)}$ Sudanese News Agency Headquarters Khartoum, 24/6/2013 
images.

- Create bilateral and multilateral agreements between African countries to combat trafficking in human beings.

\section{REFERENCES}

1. Rami Metwally Judge: Combating Trafficking in Human Beings - Arab Renaissance House - Cairo - 1998

2. Abdul Qadir Al-Sheikhli: Crimes of trafficking in human beings and human organs and their penalties in Islamic law, Arab laws and international law - Halabi rights publications - Beirut, Lebanon - 1 - 2009

3. Abdullah Saud Al-Sarani: The relationship between illegal immigration and the crime of human trafficking and trafficking Naïf University for Security Sciences - Riyadh 1 - 2010

4. Sohini Bhattacharya Chakraborty \& Mohd Zafar Shaikh, Hybrid Deformed Identity Crime Detection, International Journal of Applied Engineering Research and Development (IJAERD), Volume 4, Issue 2, March - April 2014, pp. 81-88

5. Mohammed Yahiya: International efforts to combat human trafficking - Riyadh - Naif University for Security Sciences - - 2 2010

6. Saad al-Din Mas'ad Hilali: The new in Islamic jurisprudence contemporary - Library Wahba - Cairo -2010

\section{Research Papers}

- Emily Kelly: the crisis of international human organ trafficking solutions address the roots of the case: a report by the Journal of the Faculty of Law, Boston University

- Hassan Hamidiou: The phenomenon of trafficking in organs is growing frighteningly in the Horn of Africa - a press investigation - Al Arabiya Net - 28 January 2014

- Adel Hassan Ali: Human trafficking criminalization and coping mechanisms - Center for Studies and Research Naif Arab University for Security Sciences - Riyadh 20012

- Vladimir MK Kelly: Trafficking in Human Organisms - Forced Migration Bulletin - 2014

\section{International Conventions and Conventions}

- The United Nations Convention against Transnational Organized Crime is a United Nations-sponsored multilateral treaty against organized crime.

- International Convention to Prevent, Suppress and Punish Trafficking in Persons, Especially Women and Children, 2000

- Global Program against Trafficking in Human Beings - United Nations, New York, 2006

- African Charter on Human and Peoples' Rights No. 18, Nairobi (Kenya), June 1981

- Arab Charter on Human Rights, League of Arab States, 22 May

\section{Sudanese Laws}

- Sudan Constitution for the year 2005 
- $\quad$ The Anti-Human Trafficking Act, 2014

- $\quad$ The Sudanese Child Rights Act 2010

- $\quad$ The Criminal Code of 1991

- $\quad$ Law of members and human tissues 1978 